\title{
The Specific Definition of Ecoterrorist Organizations in the USA and Russia
}

\author{
Galina Isaakovna Gribanova \\ St. Petersburg State University, \\ 7-9 Universitetskaya Embankment, \\ St. Petersburg, 199034, Russia; \\ Corresponding Author \\ Elena Nikolaevna Karatueva \\ St. Petersburg State Agrarian University, \\ 2 Peterburgskoe Highway, Pushkin, \\ St. Petersburg, 1966o1, Russia
}

DOI: https://doi.org/10.36941/ajis-2022-0034

\begin{abstract}
Nowadays there are two main interpretations of the concept of "ecoterrorism". According to the first interpretation, environmental organizations are classified as ecoterrorist organizations that fight for animal rights and against pollution using violent methods of a criminal nature. In conformity with the second interpretation, the concept of ecoterrorism is interpreted more broadly and includes acts of deliberate damage to the environment to achieve certain political and other goals. After conducting a comparative political and legal analysis of ecoterrorist organizations in different countries (primarily, the United States and Russia) and their activities in national legislations, the authors of the article have concluded that the absence of a single and internationally recognized definition of ecoterrorism is associated with the ideological assessment of the phenomenon of "terrorism", on the one hand, and with the clash of not only different concepts but also various methodologies typical of the political and legal field of a given country, on the other hand. Due to various interpretations of environmental terrorism, a list of generally recognized international ecoterrorist organizations has not been compiled, which hinders any counteraction to ecoterrorism.
\end{abstract}

Keywords: ecoterrorism, environmental organizations, domestic terrorism, international terrorism

\section{Introduction}

The priority directions of the internal policy of any state include environmental problems. These issues can arise due to objective difficulties in the interaction between nature and society and subjective actions of organizations and individuals deliberately damaging the environment. In most cases, they are caused by the desire to make a profit and increase income despite any environmental damage. However, humankind faces the fact that environmental crimes are not caused by the economy but rather politics, in other words, criminal activities in the field of ecology that pursue political goals. This refers to the phenomenon of "environmental terrorism". 
In modern science, there are two different understandings of the term "environmental terrorism". Firstly, these are radical actions of environmentalists, for example, environmentalist organizations that fight for animal rights and against pollution of ecosystems using violent methods of a criminal nature. Secondly, it is deliberate pollution of the environment (including with the use of biological, chemical, nuclear and other agents) to achieve certain political and other goals.

Despite a real threat of ecoterrorism, there is no unified approach to the definition of this type of crime in international law and national legislation of many countries, which makes it difficult to counter this extremely dangerous political phenomenon.

\section{Literature Overview}

Many foreign and Russian scholars have defined environmental terrorism and studied its possible unification. Such foreign authors as Alexander (2000), Amster (2006), Schofield (1999), Berkowicz, Alpas \& Ermakova (2011), etc. expanded its interpretation from the "fear" component (Alexander) to "ecoterrorism" and "enviroterrorism" as independent concepts (Berkowicz et al.). The Russian scientific literature substantiates the specifics of various approaches to the interpretation of environmental terrorism (Yamineva \& Khvoshchev, n.d.), endows it with a political ideology of violence (Tislenko, 2013), limits to illegal actions at hazardous facilities (Zubarev, 2017), highlights both criminological and criminal prerequisites for combating environmental terrorism (Dubovik, 2018) and defines it as the most dangerous crime, calling it "superterrorism" (Fedorov, 2002). As for the classification of ecoterrorist organizations, some scholars (Ryzhenkov, 2017) emphasize the need to distinguish between radical ecological groups and the so-called "classical terrorists" since their goals differ significantly. The others pay more attention to national branches of extremist ecological organizations (Ovchinskii \& Kochubei, 2009). The evolution of the US legislation in the field of combating terrorism has been sufficiently studied (Efremov, 2017).

In general, scientific efforts were reduced to searching for the most acceptable approaches for the international community to determine the essence of environmental terrorism and its classification. They allowed qualifying crimes against the environment as ecoterrorism. However, the issue of recognizing organizations that commit ecoterrorist acts as terrorist and including them into the official lists of terrorist organizations has practically not been studied in the relevant scientific literature. Within the framework of this study, we try to fill this gap.

\section{Methods}

We need to compare organizations classified as terrorist in Russia and the United States to highlight ecoterrorism in conformity with different approaches to defining environmental terrorism. This allows revealing the state's attitude to terrorism based on organizations posing threats to national security.

This study is based on comparative political and legal analysis. Being a qualitative method of political research, it represents the development of the normative-institutional method under the current conditions. According to this method, the normative approach inherent in the classical normative-institutional method operating with values-based assessments of research objects and results is implemented by using the criteria of such assessments presented in the form of legal norms.

At the first stage of our scientific research, we put forward the following theoretical hypothesis: the absence of a single and internationally recognized definition of ecoterrorism is associated with the ideological assessment of the phenomenon of "terrorism", on the one hand, and with the clash of not only different concepts but also various methodologies typical of the political and legal field of a given country, on the other hand. The complex nature of this process makes it difficult to form a sufficient and solid regulatory framework for classifying certain criminal acts as terrorist.

The methodological basis and toolkit for the further political and legal analysis are the contentbased analysis of regulatory acts, in which the unit of analysis is a legal norm and its officially 
recorded interpretation. The set of regulatory acts and documents that we selected for content analysis was determined by the above-mentioned theoretical hypothesis. We mostly considered criminal codes and national laws of various countries to identify differences in approaches to defining environmental terrorism only by relying on the legal interpretation of the term enshrined in international legal acts.

This analysis included both legal and political components. The legal component consists in analyzing the content of regulatory acts for the compliance of the decisions and actions made by public authorities and their officials with the Constitution, international acts on human rights and civil freedoms, and the current legislation. The political component consists in analyzing the political orientation of the decisions and actions made by public authorities and their officials recorded in regulatory and other official documents, as well as their political and ideological motivation.

\section{Results}

\subsection{Comparative Analysis of the Legal Definition of Ecoterrorism: General and Specific}

The definitions of ecoterrorism differ in the legislation of different countries, which is reflected in Table 1.

Table 1: Definition of the "ecoterrorism" concept in national legal acts

\begin{tabular}{|c|c|c|}
\hline Country & Source & Terms revealing the essence of ecoterrorism \\
\hline \multirow{3}{*}{ Russia } & $\begin{array}{l}\text { Article } 358 \text { of the Criminal Code } \\
\text { of the Russian Federation }\end{array}$ & $\begin{array}{l}\text { Ecocide is massive destruction of the animal or plant kingdoms, contamination of the } \\
\text { atmosphere or water resources, and also commission of other actions capable of causing an } \\
\text { ecological catastrophe (Criminal Code of the Russian Federation No. 63-FZ, 1996). }\end{array}$ \\
\hline & $\begin{array}{l}\text { Environmental Doctrine of the } \\
\text { Russian Federation approved by } \\
\text { Order of the Government of the } \\
\text { Russian Federation of August } \\
\text { 31, 2002 No. 1225-r. }\end{array}$ & $\begin{array}{l}\text { Terrorism that poses a threat to the environment, in particular, terrorist acts that cause } \\
\text { environmental degradation (Executive Order of the Government of the Russian Federation No. } \\
\text { 1225-r., August 31, 2002). }\end{array}$ \\
\hline & $\begin{array}{l}\text { Federal Law of December } 30 \text {, } \\
2020 \text { No. } 492-F Z \text { "On Biological } \\
\text { Safety in the Russian } \\
\text { Federation" }\end{array}$ & $\begin{array}{l}\text { Terrorist threats: accidents, terrorist acts and/or sabotage at facilities where sources of } \\
\text { biological threat (hazard) are located and/or work is carried out using pathogens; } \\
\text { Implementation of terrorist acts and/or sabotage using pathogens, the use of biological } \\
\text { technologies and other related technologies for the development, production and use of } \\
\text { pathogens as biological weapons, as well as the uncontrolled implementation of dangerous } \\
\text { man-made genetic activity, including the use of genetic engineering technologies (Federal Law } \\
\text { No. 492-FZ, 202o). }\end{array}$ \\
\hline \multirow[t]{2}{*}{ USA } & FBI & $\begin{array}{l}\text { Ecoterrorism is the use or threatened use of violence of a criminal nature against innocent } \\
\text { victims or property by an environmentally-oriented subnational group for environmental- } \\
\text { political reasons, aimed at an audience beyond the target, and often of a symbolic nature } \\
\text { (Jarboe, 2002). }\end{array}$ \\
\hline & The United States Code & $\begin{array}{l}\text { Federal crimes of terrorism: with the use of biological, chemical weapons, nuclear materials, } \\
\text { the threatened use of atomic weapons or weapons of mass destruction against the United States } \\
\text { (The United States Code, n.d.). }\end{array}$ \\
\hline France & The French Criminal Code & $\begin{array}{l}\text { Environmental terrorism is "deliberate introduction into the atmosphere, soil, subsoil or waters, } \\
\text { including territorial sea waters, by one perpetrator or by an organized group to seriously disrupt } \\
\text { public order by means of intimidation or terror, substances that can pose a danger to the health } \\
\text { of people, animals or the environment" (The Penal Code of France, 2019). }\end{array}$ \\
\hline Ukraine & $\begin{array}{l}\text { Law of Ukraine "On Fight } \\
\text { against Terrorism" of March 20, } \\
2003 \text { No. 638-IV }\end{array}$ & $\begin{array}{l}\text { Technology terrorism is "crimes that are committed with the purpose of terrorist use of nuclear, } \\
\text { chemical, bacteriological (biological) and other weapons of mass destruction or their } \\
\text { components, other hazardous substances on human health, means of electromagnetic action, } \\
\text { computer systems and communication networks including the capture, disable and destroy } \\
\text { potentially dangerous objects that directly or indirectly created or threatened danger of an } \\
\text { emergency caused by these actions and are a danger to staff, population and environment, } \\
\text { create conditions for accidents and disasters manmade disasters" (Law of Ukraine No. 638-IV, } \\
\text { 2003). }\end{array}$ \\
\hline Georgia & $\begin{array}{l}\text { The Criminal Code of Georgia, } \\
\text { Article } 324\end{array}$ & $\begin{array}{l}\text { Technology terrorism is "the use of nuclear, radiological, chemical or bacteriological (biological) } \\
\text { weapons or components thereof, pathogenic microorganisms..." (Serebrennikova \& Lebedev, } \\
\text { 2019, p. 18). }\end{array}$ \\
\hline
\end{tabular}

However, the main and indisputable property of the above-mentioned definitions is damage to the environment or the fight against those causing such destruction. Since such crimes can be committed by various organizations, appropriate measures shall be taken at the international level to prevent 
and investigate these crimes.

Nowadays the problem of punishment for committing an act of environmental terrorism is both in the absence of any penalty for such an act (including punishment for committing an ecoterrorist act when its essence is described in the state's criminal code and national legislation) and the absence of an organization committing crimes that can be included as ecoterrorist into the officially approved list of terrorist organizations. Many terrorist acts that can be classified as ecoterrorist are committed by organizations that are not officially included in such lists. Since there is a problem of identifying acts of environmental terrorism, the crimes committed are often called crimes against various types of property or simply sabotage. If an organization is officially recognized as a terrorist one, the crimes it committed de jure become terrorist, which greatly simplifies the problem of combating environmental terrorism (Foreign terrorist organizations, n.d.).

To compare approaches to defining the concept of environmental terrorism, we present the Russian and American viewpoints on the issue since these countries faced real terrorist threats and were forced to improve the system of national legislation to fight against terrorism.

The sources under consideration show that there is no unambiguous legal definition of environmental terrorism. Only the French Criminal Code provides a clear definition of "environmental terrorism" as the deliberate infliction of damage on the environment, human beings and animals (The Penal Code of France, 2019).

In the criminal codes of Georgia (Serebrennikova \& Lebedev, 2019) and Ukraine (Law of Ukraine No. 638-IV, 2003), the studied phenomenon is designated by the term "technology terrorism".

In the US legal system, there are different approaches to defining environmental terrorism and terrorism with the use of biological, chemical and nuclear weapons. The first one refers to the socalled "domestic" terrorism. According to the FBI, it is a type of terrorism consisting in illegal actions of some environmental organizations that protect animal rights and, thus, is a special type of terrorism. Among the selected terrorist organizations, a separate position is held by "ecological terrorist organizations" in the US Patriot Act (2001). Biological, chemical and nuclear terrorism in the American legal interpretation is not included in the concept of environmental terrorism but are independent types of radicalism enshrined as federal crimes of terrorism in the United States Code (The United States Code, n.d.).

The Russian legislation does not mention the term "environmental terrorism". The ecological doctrine of the Russian Federation approved by Order of the Government of the Russian Federation No. 1225-r (2002) contains the concept of "terrorism that poses a threat to the environment". The Criminal Code of the Russian Federation mentions the "ecocide" term. Penalties are provided for general crimes against the environment listed in Chapter 26 "Environmental Crimes" (Criminal Code of the Russian Federation No. 63-FZ, 1996).

Federal Law of December 30, 2020 No. 492-FZ "On Biological Safety in the Russian Federation" contains no definition of "biological" or "environmental" terrorism. The main biological threats comprise terrorist acts with the use of pathogens and terrorist acts on potentially dangerous biological objects (Federal Law No. 492-FZ, 2020).

While analyzing the sources, it was important to understand the national interpretation of environmental terrorism to highlight the principle of including one or another organization carrying out terrorist acts against the environment into the official lists of terrorist organizations. We also considered legal sources mentioning environmental terrorism, environmental crimes and environmental terrorist organizations, or terrorist organizations that do not have the status of ecoterrorist but undertake illegal activities against the environment. In addition, the official lists of terrorist organizations in the United States and Russia were examined, including the list of organizations qualified as terrorist in the CSTO countries.

The table below shows the main regulatory legal acts of the research objects (Russia and the USA), which are the basis for countering terrorism (the latter can be called environmental). 
Table 2: The main regulatory legal acts on countering environmental terrorism in Russia and the United States

\begin{tabular}{|c|l|}
\hline Russia & $\begin{array}{l}\text { The Criminal Code of the Russian Federation (Criminal Code of the Russian Federation No. 63-FZ, } \\
\text { 1996), Environmental Doctrine of the Russian Federation approved by Order of the Government of } \\
\text { the Russian Federation No. 1225-r (August 31, 2002), Article } 8 \text { of Federal Law No. 492-FZ "On } \\
\text { Biological Safety in the Russian Federation" (December 30, 2020), Federal Law "On Counteracting } \\
\text { Terrorism" No. 35-FZ (2006), Federal Law No. 114-FZ.)."On Combating Extremist Activity" (2002). }\end{array}$ \\
\hline USA & $\begin{array}{l}\text { The Biological Weapons Anti-Terrorism Act of 1989 (BWATA) - Public Law 101-298) (1990), Anti- } \\
\text { Terrorism and Effective Death Penalty Act (1996), the USA Patriot Act (2001), the Homeland } \\
\text { Security Act (HSA) (2002), the Safety Act of 2002; the U.S.C. (The United States Code, n.d.). }\end{array}$ \\
\hline
\end{tabular}

\subsection{Specific Features of Terrorism in the USA}

In the United States, the approach to identifying terrorist organizations differs in relation to participants in terrorist acts. Its national legal doctrine distinguishes between the concepts of "domestic" and "external" (foreign or international) terrorism.

\subsubsection{Domestic terrorism in the United States}

"Domestic" terrorist attacks are committed in the United States by citizens or persons permanently residing in the territory of the state. The FBI describes this type of terrorism as violent, criminal acts committed by individuals and/or groups to achieve ideological goals arising from internal impacts, including political, religious, social, racial or environmental (Federal Bureau of Investigation, n.d.).

The growing attention to the problem of terrorism on the part of legislators, including the restriction of the rights of citizens, was influenced by the terrorist acts of September 11, 2001 and the spread of anthrax letters. After the tragedy, the USA Patriot Act or the Uniting and Strengthening America by Providing Appropriate Tools Required to Intercept and Obstruct Terrorism Act of 2001 was adopted (USA Patriot Act, 2001), which provided the government and the police with more powers to oversee citizens.

The USA Patriot Act classified domestic terrorism according to various indicators that have an illegal context and highlighted the following acts:

1) Associated with acts dangerous to human life that are a violation of the criminal laws of the United States or any State;

2) Intended to intimidate or coerce a civilian population; to influence the policy of a government by intimidation or coercion; occur primarily within the territorial jurisdiction of the United States (Blishchenko, 2013).

Despite the mention of the "domestic terrorism" term in the Patriot Act, there is no crime in the US criminal law that would be called "domestic terrorism". Crimes that can be regarded as domestic terrorism are punished according to specific laws, for example, for the murder of federal agents or for the "attempted use of explosives to destroy a building involved in interstate commerce" (USA Freedom Act, 2015).

In 2015, the USA Patriot Act was replaced by the USA Freedom Act prohibiting the National Security Agency (NSA) (Petchesky, 1981) from eavesdropping on conversations, practicing electronic surveillance and collecting information about US citizens (surveillance can be validated only through a court decision). Between 2016 and 2018, the FBI arrested 355 domestic terrorism suspects. According to the FBI, most of them were motivated by racist and anti-government ideology.

The US Department of Justice mentions several types of extremist organizations that pose an internal terrorist threat:

1. Anti-abortion organizations; 
2. Environmental terrorist organizations;

3. Racial terror;

4. Right-wing extremism.

Although only illegal actions of environmental terrorist organizations can be attributed to environmental crimes, judging by the names of terrorism types, the activities of organizations related to violence against abortion, racial terrorism and right-wing extremism can also be regarded as environmental or biological terrorism.

After analyzing all types of domestic terrorism, we can conclude that the majority of terrorist organizations operating in the territory of the United States can be combined into three large groups based on the protection of the rights of certain subjects.

1. Organizations associated with violence against abortion to defend the rights of the unborn;

2. Environmental terrorist organizations that protect animal rights;

3. Racist and nationalist organizations that defend the rights and emphasize the superiority of a particular race or nation.

\subsubsection{Anti-Abortion Violence Movement}

The movement has been developing in the United States and Canada since the 1970s. The main goal of the terrorist acts committed is to draw public attention to the problem of abortion and its legal prohibition.

The movement embraces numerous groups that attack and cause damage to abortion clinics. Despite their aggressive rhetoric, the motto of such organizations is saving lives, which is reflected in the following names: Advocates for Life, American Coalition of Life Activists, Christian Action Group, Defensive Action, Pro-Life Action Network, Rescue America, Army of God (AOG), etc. (Rev. Donald Spitz, n.d.).

It is worth mentioning that organizations advocating the natural and inalienable right to life of even an unborn person use not only such "classical" methods of ecoterrorism as arson, explosion, destruction and damage of property belonging to clinics conducting abortions but also murder doctors and politicians who support these acts.

The organization has many adherents and finances its activities from its own funds, which covers the costs not only for the commission of terrorist acts but also for the creation of training centers (teaching the organization and planning of military operations), as well as for campaigning with the help of their own magazine "Life Advocate" and other periodicals.

The illegal activities of anti-abortion organizations comprise other radical groups. Anti-abortion activists are not limited to their own terrorist network and interact with other radical movements, among which should be highlighted the right-wing movement "Militia", the Ku Klux Klan, the radical US Taxpayers Party and the anti-taxation "Posse Comitatus".

Organizations with "multidirectional" activities include the "Army of God" and the "Phineas Priesthood."

The Army of God (Eko-terrorizm, n.d.) is a scattered network of individuals and groups linked by ideology and a determination to use force to end abortion in the United States. It is also known for its homophobic activity. For example, acts of violence against abortion escalated in the mid-1990s and culminated in a series of bombings committed by Eric Robert Rudolph. These targeted not only two abortion clinics but also an LGBT nightclub and the 1996 Summer Olympics in Atlanta. The Army of God demonstrated its aggressive position and took credit for the clinic bombings by sending messages to newspapers.

\subsubsection{Ecoterrorist organizations}

Ecoterrorist organizations are organizations that protect animal rights with extremely radical methods. The ideology of one ecoterrorism direction is based on the idea of biocentrism which 
assumes that "people are ordinary members of a biological community", therefore all living beings should have equal rights and the ability to protect themselves in accordance with the law. Other ecoideological movements aim at returning the environment to its natural pre-industrial state with the help of extremist methods (Jarboe, 2002).

The US Federal Bureau of Investigation (FBI) defines ecoterrorism as "...the use or threatened use of violence of a criminal nature against innocent victims or property by an environmentallyoriented subnational group for environmental-political reasons..." and holds ecoterrorists liable for causing material damage to the US economy of \$200 million between 2003 and 2008 (Jarboe, 2002).

To counteract the destructive activities of radical environmentalists, most of the US states have passed laws providing punishment for such crimes. In 2006, a special law was adopted in the USA against one kind of internal terrorism (i.e., environmental terrorism). The Animal Enterprise Terrorism Act (P.L. 109-374) (Animal Enterprise Terrorism Act, 2006) establishes criminal penalties and compensation for damages caused by terrorist activities to protect animal rights.

Environmental organizations that have been accused of using terrorist methods in the United States are the Animal Liberation Front (ALF), Earth Liberation Front (ELF), Sea Shepherd Conservation Society, People for the Ethical Treatment of Animals (PETA), Earth First! and Hardesty's Avengers Rescue Coalition (USA Patriot Act, 2001).

Due to the growing threats posed by radical environmentalists, any environmental organization could fall under the FBI's suspicion. In 2010, the FBI was criticized in reports of the US Department of Justice for unreasonable surveillance (and placement on the Terrorist Screening Database) on members of animal rights groups, including Greenpeace and PETA, between 2001 and 2006. In 2002, the Sea Shepherds Conservation Society was first considered in the context of environmental terrorism (Sea Shepherd conservation..., 2013).

The main reason for classifying this ecological organization as terrorist was its interference in the fight against whaling, hunting for seals and fishing using terrorist methods. In 1986, the group caused damage of nearly $\$ 1.8$ million to the Icelandic whalers' equipment. In 1992, they paralyzed the activities of two Japanese ships drift-netting for squid by cutting their nets and throwing pungent bombs on board (Earth First, n.d.).

The environmental organization led by Edward Abby "Earth First!" is known since 1980. Its activists hammered metal rods into tree trunks to damage chainsaws that contributed to the emergence of the "ecoterrorism" term in relation to environmental organizations (Animal Liberation Front, n.d.).

Gradually, environmental organizations in the United States increased their power and united larger communities. Thus, the ecological movement "ELF" founded in 1992 merged with the "ALF" which began its activities in England in 1979 (Ekologicheskii terrorizm, n.d.). Terrorists used arson without harming people or animals. One of the most notorious crimes is the arson of a residential complex in Woodinville, the Seattle suburb, in March 2008 due to the non-ecological nature of these buildings. A banner left at the crime scene indicated that this complex was not as "green" as advertised. In 2001, the FBI called the ELF "one of the most active extremist movements in the United States" and a clear "terrorist threat" (FBR: ekoterroristy - novaya ugroza Amerike, n.d.).

In addition to the world-renowned environmental organizations, the FBI identified several "local" terrorist groups that use extremist methods to protect animal rights. For instance, these include the Save Reserve Coalition responsible for a series of arson attacks in Arizona that cost more than \$5 million; Stop Huntingdon Animal Cruelty; Hardesty's Avengers Rescue Coalition who pierced trees with metal rods in the Hardesty Mountains in Willamette National Forest in 1984 (The Covenant..., n.d.), etc.

After analyzing activities of the main US ecoterrorist organizations related to "domestic terrorism", it can be assumed that they are classified as terrorist mainly based on material damage caused to the US economy.

Acts of ecoterrorism that led to injuries and deaths are associated not with specific organizations but with independent ecoterrorists. For example, the US mass media (ABC, The New 
York Times, Time magazine and USA Today) connect terrorist attacks (the use of letter-bombs) that led to 23 injuries and three deaths with the name of the well-known US environmental activist Ted Kaczynski, a.k.a. the Unabomber.

The National Animal Interest Alliance compiled a comprehensive list of major extremist and eco-criminal acts of animal rights terrorism starting from 1983. Since 2012, the FBI has noted a decrease in ecoterrorist incidents in the United States, especially after efficient prosecution of ecoterrorists. Nevertheless, the problem remains relevant as ecoterrorism continues to surpass other manifestations of US domestic terrorism in terms of their number.

\subsubsection{Right-wing racist and nationalist organizations that are classified as eco-terrorism}

Among the right-wing extremist organizations, some groups are not officially recognized as terrorist. However, they can be attributed to ecoterrorist if environmental terrorism is regarded as deliberate infliction of harm to environmental objects according to several features. Since the definition of environmental terrorism in the United States embraces only the crimes of radical environmentalists, the other terrorist acts in one way or another related to environmental pollution or the use of various pathogens fall under other types of terrorism (biological, chemical, nuclear, etc.).

Thus, the extremist Christian organization the Covenant, the Sword and the Arm of the Lord (CSA), which actively functioned in 1970-1980, professed the ideology of white supremacy and developed a plan for infecting tap water with cyanide in major cities of the United States. In addition, a CSA member, Stephen Scott, pleaded guilty to the federal court in Arkansas for blowing up a gas pipeline near Fulton in 1983 (The Covenant..., n.d.).

A revolutionary movement that opposed the US imperialism and the Vietnam War called Underground (1970) tried to demonstrate the inability of the federal government to fulfill its functions by poisoning the city's sewers with biological and chemical pathogens. As agents of terrorist acts, they selected the so-called incapacitants that cause temporary damage to human health.

Inspired by the ideology of ecoterrorism, college students formed the extremist organization RISE (1972). Their goal was to create an ideal world with a minimum number of people who were regarded as a source of environmental pollution. The first attack failed as public authorities discovered microbial organisms designed to poison people on a large scale.

Members of the Rajneeshe Cult (a religious sect) poisoned voters with Salmonella to win local elections in the Dalles, Oregon, in 1984. As a result of this terrorist attack, 750 people were injured but the sectarians were apprehended and sentenced to 4.5 years of imprisonment under Article "Tampering with consumer products" (Supotnitskii, 2004).

In the 1990s, members of the Minnesota Patriots Council, a racist radical organization, attempted to carry out a terrorist attack by applying ricin to the skin of federal officials. Fortunately, the crime was averted thanks to an FBI informant. As a result, four terrorists were arrested (Ekstremizm. Made in USA, n.d.).

Since the threat posed by domestic terrorist organizations is quite significant, the US authorities offer to pass legislation providing for the establishment of additional offices in the Department of Justice, Department of Homeland Security and the FBI to combat ultra-right violence. Although the adoption of the corresponding law was included in the political agenda in 2020, it has not been adopted yet.

\subsubsection{International terrorism}

Foreign or international terrorism in the United States refers to acts of terrorism against the property of the United States or US citizens committed by individual terrorists and foreign terrorist organizations. Under Section 219 of the Immigration and Nationality Act (INA), as amended, Foreign Terrorist Organizations (FTO) are foreign organizations that are not located in the United States, 
designated by the Secretary and posing a threat to the United States. The list of foreign terrorist organizations is provided in the report of the US Department of State (n.d.).

The activity to identify and approve new foreign terrorist organizations is ongoing and is a rather complex process. The Office of the Coordinator for Counterterrorism in the US Department of State monitors extremist groups around the world. When identifying candidates for inclusion into the list of potential terrorist organizations, legislators consider not only their actual attacks but also the participation of groups in the planning and preparation of acts of violence, or even their ability and willingness to commit such crimes.

The decision to include some organization on the list of foreign terrorist organizations made by the United States Secretary of State in agreement with the Prosecutor General and the United States Secretary of the Treasury is submitted to the US Congress, where it is considered within seven days. Upon expiration of this period, the notification that some organization was classified as terrorist is published in the Federal Register and then comes into force. For all the severity of such an action, these organizations are not deprived of the right to challenge this judicial decision. According to the Intelligence Reform and Terrorism Prevention Act of 2004, a foreign terrorist organization might petition to have its "terrorist" label revoked.

Most organizations designated as terrorist are Islamist extremist, nationalist or separatist groups. Among them, only one terrorist organization can be considered environmental or biological. On October 8, 1997, the Japanese organization Aum Shinrikyo was included in the FTO list.

Aum Shinrikyo members became known to the world community after the 1994 and 1995 terrorist attacks using the Sarin chemical warfare agent, which had grave consequences for the population. In 1994, seven people were killed and 280 were seriously injured in Matsumoto. The Tokyo subway attack of 1995 resulted in the deaths of 12 people and some 5,500 others were injured to varying degrees. After his arrest on May 28, 1998, Shoko Asahara admitted that the sect was planning a gas attack in the United States and sent there a container with Sarin (Nakamura, 1997).

At the initial stage, terrorists used mainly biological agents. In April 1990, the sect members sprayed a substance of their own production, which they believed to be Botulinum toxin, near the Japanese parliament. In 1993, it was planned to thwart the wedding of Japan's Crown Prince and poison subway passengers in the same way. In June 1993, the leader of Aum Shinrikyo decided to switch to more toxic and dangerous pathogens. In a district of Tokyo, members spread anthrax pathogens but their terrorist attempt was unsuccessful (Nakamura, 1997).

Thus, only chemical warfare agents glorified the infamous Aum Shinrikyo. The danger of this terrorist organization consisted in the fact that the group acquired the status of a sect with a special ideology of a "religion for the elite", which made it especially attractive to the enlightened youth, including students from the Japanese elite universities.

\subsection{Ecoterrorist Organizations in the Russian Federation}

Terrorist organizations in the Russian Federation are organizations included in the Unified Federal Register of Organizations, both foreign and international, recognized as terrorist under the Russian legislation (Federal Security Service of the Russian Federation, 2021). First created in 2008, the list is updated annually. The last amendments were made on August 31, 2020, and remain relevant at the moment. Accordingly, the main threat to the national security of the Russian Federation is mostly posed by Islamist organizations. Among 22 terrorist organizations, only the Aum Shinrikyo International Religious Association (Aum Shinrikyo, AUM, Aleph) has an anti-environmental orientation and is recognized as terrorist by the decision of the Supreme Court of the Russian Federation of September 20, 2016 No. AKPI 16-915C which entered into force on October 25, 2016.

In Russia, the sect was officially registered in early 1992. From 1993 to 1994, Aum Shinrikyo openly functioned as a religious sect that became especially attractive to people who lost faith in the state during the roaring 1990s. The sect actively used mass media. Aum Shinrikyo promoted its activities in weekly radio and television programs. The organizers spent about half a million rubles on 
a weekly hour-long program at the Mayak radio station and a half-hour program on the $2 \times 2$ Channel (Supotnitskii, 2013). Visual agitation in the form of colored leaflets and posters was distributed in different districts of Moscow. It is noteworthy that the organization, which was officially recognized as terrorist 24 years after it began functioning in the Russian Federation, actively used the resources of the Russian political elite. The head of the cult contacted Oleg Lobov (Secretary of the Security Council of the Russian Federation) (The mystery of "Aum" in Russia, 2013) and Yury Luzhkov (Mayor of Moscow) (Music on Saturdays..., 2007).

In addition to the organizations included in the list of terrorist organizations in the Russian Federation, there is a "List of organizations recognized as terrorist and extremist in the CSTO member states" (Committee of Secretaries of Security Councils CSTO, 2016). Since the Russian Federation is a full-fledged member of the Collective Security Treaty Organization, it must recognize the listed organizations in its territory. Based on the list of organizations that pose a threat to the national security of the CSTO countries, they can be conditionally divided into two groups: terrorist and extremist.

The Federal Law "On Combating Extremist Activity" of 2002 interprets the concept of "extremist activity" broader than the concept of "terrorist activity" since terrorism can be viewed as a manifestation of extremism (Federal Law No. 114-FZ, 2002).

According to the Federal Law "On Countering Terrorism" No. 35-FZ (2006), an organization can be recognized as terrorist if it prepares or commits extremist acts that provide for punishment in conformity with Articles 280, 2821 and 2822 of the Criminal Code of the Russian Federation (Article 24).

Terrorist attacks mainly aim at objects of public safety and public order (Section 9 of the Criminal Code of the Russian Federation). Their activity is characterized by violence or the threat of violence, as well as an atmosphere of fear in society, which semantically is included in the definition of terrorism ("terror" as fear or horror). Extremist organizations can confine themselves to propaganda and agitation, and do without acts of direct violence. At the legal level, crimes related to manifestations of terrorism and extremism are placed in different chapters of the Criminal Code of the Russian Federation (Criminal Code of the Russian Federation No. 63-FZ, 1996).

Thus, the key difference in classifying an extremist organization as terrorist is the commission of specific offenses that fall under certain articles of the Criminal Code.

Out of the total number of extremist organizations, only three are officially recognized as terrorist: Aum Shinrikyo, the Syndicate "Autonomous Combat Terrorist Organization (ABTO)" and the Ukrainian organization "Tryzub named after Stepan Bandera". All of them belong to different countries and are classified as "terrorist" by courts of different levels ${ }^{1}$. Only one organization in this list (Aum Shinrikyo) can be considered biological by the nature of the agents used. It became known all over the globe due to the use of biological and chemical agents, in particular, Botulinum toxin and the Sarin chemical warfare agent.

The ALF in Russia is not officially recognized as terrorist but this did not prevent its supporters from attacking the Faculty of Biology at Lomonosov Moscow State University and releasing laboratory animals. The corresponding inscriptions and logos testified to the fact that this organization is ecoterrorist (Mikhel \& Borovik, 2010).

Among organizations that are not officially terrorist, there are radical groups that use pathogens of various nature to achieve their political goals. Moreover, they might not have a predominantly

\footnotetext{
${ }^{1}$ By the decision of the court of Astana, the Republic of Kazakhstan, of November 17, 2006, Aum Shinrikyo was recognized as terrorist and its activities were prohibited in the territory of the Republic of Kazakhstan. By the decision of the Moscow City Court of June 28, 2013, the ABTO was recognized as terrorist and its activity was prohibited in the territory of the Russian Federation. On November 27, 2013, the Supreme Court of the Russian Federation recognized the ban on its activities as legal. By the decision of the Supreme Court of the Russian Federation of November 17, 2014 "Tryzub named after Stepan Bandera" was recognized as terrorist.
} 
anti-ecological orientation. On July 21, 2010, the work of the Baksan hydroelectric power station was sabotaged (A terrorist attack..., 2020). According to preliminary information, the terrorist attack was committed by militants of the Islamist group "Baksan Jamaat" ${ }^{\text {. }}$. The Investigative Committee under the Prosecutor's Office of the Russian Federation initiated a criminal case under six articles of the Criminal Code of the Russian Federation: Sabotage, Encroachment on the Life of an Officer of a Law Enforcement Agency, Illegal Deprivation of Liberty, Illegal Manufacture and Theft of Weapons and Explosives (Articles 281, 317, 127, 222, 223). However, the crime was not officially identified as a terrorist act. The Baksan Jamaat is not included in the list of terrorist organizations, so the possibility of bringing its members to justice for terrorist crimes is significantly reduced.

The dangers associated with the use of biological, chemical or radioactive weapons can be actively used to draw attention to political issues during periods of national political crises. To prove his status of a "dangerous" terrorist, Shamil Basayev declared that he possessed containers with bacteriological and radioactive weapons in 1995. On November 21, an NTV correspondent, Elena Masyuk, actually discovered a container with radioactive materials in Izmailovsky Park. Moreover, its whereabouts were indicated by Shamil Basayev himself. Security officials had different opinions about the reality of this threat. Thus, Arkady Volsky, the deputy chief of the Russian delegation in Chechnya, said that it was "Basayev's handiwork". A high-ranking FSB officer, who wished to remain anonymous, suggested that it was a made-up story since the container was not dangerous to people. According to the Ministry of Emergency Situations, a container at a distance of $1 \mathrm{~cm}$ emits $2 \mathrm{x}$-rays per hour, and at a distance of 1 meter 6oo microroentgens per hour (Someone steals..., 1995).

In 1998, Shamil Basaev and Movladi Udugov established the "Congress of the Peoples of Ichkeria and Dagestan" (KNID). Its headquarters did not have a permanent location since the supreme body was the KNID Congress. The organization focused on inciting extremism and separatism in various regions of Russia to "liberate the Muslim Caucasus from the Russian imperial yoke" (Kudryavtsev, 200o). On February 4, 2003, the Supreme Court of the Russian Federation recognized this organization as terrorist.

To prevent possible environmental crimes, the Russian Federation adopted the Environmental Doctrine of the Russian Federation No. 1225-r (2002). It defines the priority activities of the Russian state and society to ensure the environmental safety of the Russian Federation.

\subsection{Comparing Approaches to the Definition of Ecoterrorist Organizations in the US and Russian Legislation}

The main objective of previous research in the field of environmental terrorism was to create a unified definition. All the efforts aimed at the classification of terrorist objects. To expand the possibilities of holding organizations that commit such crimes liable, it is significant to have an opportunity to recognize them as terrorist. The next step towards combating environmental terrorism is to define the concepts of not only environmental terrorism but also ecoterrorist organizations. The scientific works under consideration should explain this phenomenon. However, we should realize that the creation of a single list of ecoterrorist organizations will in many ways help to immediately classify the results of their activities as criminal.

The events of September 11, 2001 resulted in a tightening of the anti-terrorist legislative base in the United States. The implementation of a terrorist act by an international terrorist organization required the US authorities to reconsider their attitude to the concept of terrorism and distinguish between internal and external types, thereby highlighting the different nature of potential terrorist threats.

The differentiated attitude to the concept of terrorism in the US legal system is specific due to different interpretations of its types as crimes at the legislative level. While international terrorism or

\footnotetext{
${ }^{2}$ The underground armed formation of the self-proclaimed Caucasus Emirate, in charge of the North-Eastern sector of the United Vilayat of Kabarda, Balkaria and Karachay (territories of Kabardino-Balkaria and Karachay-Cherkessia) 
"acts of terrorism that transcend national borders" are federal crimes, perpetrators of domestic terrorism are charged under specific laws for certain crimes. In addition, the high degree of danger posed by international terrorism was enshrined in a multi-stage procedure for classifying a terrorist organization as foreign or international.

It is noteworthy that among the organizations classified as domestic terrorism, the overwhelming majority can be attributed to the category of environmental ones, fighting by radical methods for the protection of animal rights (environmental organizations as defined by the FBI), the rights of unborn children (anti-abortion movement) and the rights to the superiority of a particular race or nationality (racism, nationalism). According to US law, only Aum Shinrikyo conducting terrorist attacks using biopathogens and chemicals can be called an international terrorist organization.

In the Russian legal system, the main laws aimed at combating terrorism and extremism are the Federal Law No. 35-FZ (2006) and the Federal Law No. 114-FZ (2002). Unlike the United States, there is no difference between domestic and foreign terrorism. The Unified Federal Register of Organizations, both foreign and international, recognized as terrorist under the Russian legislation (Federal Security Service of the Russian Federation, 2021) comprises all the organizations recognized as terrorist in the territory of the Russian Federation. Aum Shinrikyo is included in this list.

In addition, Russia is obliged to recognize criminal organizations from the CSTO lists as terrorist and extremist. From this list, only three organizations are recognized as terrorist by different laws and different countries. Out of these organizations, only Aum Shinrikyo can be considered ecoterrorist.

Despite common approaches to the definition of terrorist organizations in general and ecoterrorist organizations in particular, there are significant differences between the legal criteria of the United States and Russia. Undoubtedly, racist and nationalist organizations and organizations that use various poisonous substances against a person are recognized as anti-environmental. However, radical ecoterrorist organizations defending animal rights are not officially recognized as such at the legislative level in Russia. This also implies a different understanding of the definition of "environmental terrorism" in Russia and the United States. In the USA, these are radical actions of environmentalists and terrorist attacks with the use of poisonous substances falling under the categories of biological, chemical, or nuclear terrorism. In Russia, environmental terrorism is understood as any damage to the environment with the use of poisonous pathogens of various origins, or actions leading to environmental catastrophes carried out by terrorist organizations. At the same time, the Russian legal system has no single definition of such a category as "environmental terrorism". For example, the "Environmental Doctrine of the Russian Federation" mentions terrorism "posing a threat to the environment". Consequently, another important difference between the US and Russian approaches to the definition of environmental terrorism is that the official government services in the United States (FBI) give a clear definition of the concept.

It is better to present the difference between the US and Russian approaches to the definition of ecoterrorist organizations in the form of a table. The American and Russian interpretations of environmental terrorism and its differentiation into domestic and international were taken as criteria for comparison.

Table 3: Main approaches to defining ecoterrorist organizations in Russia and the United States

\begin{tabular}{|l|l|l|l|}
\hline The Russian approach & The American approach \\
\hline $\begin{array}{l}\text { Domestic eco- } \\
\text { terrorist } \\
\text { organizations }\end{array}$ & $\begin{array}{l}\text { International } \\
\text { Ecoterrorist } \\
\text { Organizations }\end{array}$ & $\begin{array}{l}\text { Domestic eco-terrorist } \\
\text { organizations }\end{array}$ & $\begin{array}{l}\text { International } \\
\text { Ecoterrorist } \\
\text { Organizations }\end{array}$ \\
\hline- & Aum Shinrikyo & $\begin{array}{l}\text { ALF; ELF, Sea Shepherd Conservation } \\
\text { Society, PETA, Earth First!, Hardesty } \\
\text { Reserves and Avengers Coalition }\end{array}$ & - \\
\hline
\end{tabular}

\footnotetext{
${ }^{3}$ Officially, there are no terrorist organizations in the Russian Federation that are classified as ecoterrorist.
} 
Under the US approach to the definition of environmental terrorism as radical actions of environmentalists, the United States recognizes internal ecoterrorist organizations that protect animal rights. However, it does not record such activities of international organizations. In Russia, there are no international or domestic ecoterrorist organizations officially recognized as terrorist based on the American concept of classifying terrorist organizations as ecoterrorist.

Following the Russian approach to identifying ecoterrorist organizations, their list includes the officially recognized terrorist sect Aum Shinrikyo that used poisonous biological and chemical agents to intimidate the population and achieve its political and religious goals. In the United States, Aum Shinrikyo officially belongs to the category of international terrorist organizations but its activities do not fall under the American definition of environmental terrorism.

\section{Conclusion}

This study has revealed the main problems in the environmental legislation of different countries after comparing the legal interpretations of environmental terrorism and the specifics of ecoterrorist organizations in the United States and the Russian Federation.

The states that have experienced the consequences of terrorist acts are constantly improving and adjusting their legal framework in relation to these offenses. Despite the active international counter-terrorism activities, there is still no single approach to the classification of ecoterrorist organizations. In the Russian legal system, there is no concept of an ecoterrorist organization and no differentiation of terrorism into domestic and international. The official lists of terrorist organizations include organizations located in different places. Domestic criminal groups that commit terrorist attacks damaging the environment are often not included in the corresponding category, therefore their actions are not classified as terrorist acts but fit the definitions of sabotage or crimes against property. Since such organizations are not identified as internal threats, they are not a priority in the field of law enforcement. Table 3 demonstrates that there are no domestic environmental terrorist organizations in Russia, although crimes against the environment are quite common there. After the events of September 11, 2001, anti-terrorist activities enshrined in the US legislation are directed towards the prevention of domestic terrorism. However, its definition of the concept is one-sided and does not include other crimes against the environment.

High efficiency in preventing and countering environmental terrorism can only be achieved through joint efforts of the international community. Despite the adoption of UN international conventions, not a single document has developed a general concept of "environmental terrorism" applicable to all countries or formed a list of generally recognized international environmental terrorist organizations, which greatly complicates the overall counteraction to international ecoterrorism. Much work in the future will aim at analyzing the methods used by terrorist organizations to identify their ability to pose threats to the environment, which will allow them to be classified as ecoterrorist and to enshrine responsibility for the crimes committed at the legislative level.

\section{References}

A terrorist attack on the Baksan hydroelectric power plant. (2020, July 21). RIA Novosti. Available: https://ria.ru/20200721/1574589221.html

Alexander, G. A. (2000). Ecoterrorism and nontraditional military threats. Military Medicine, 165(1), 1-5.

Amster, R. (2006). Perspectives on ecoterrorism: catalysts, conflations, and casualties. Contemporary Justice Review, 9, 87-301.

Animal Enterprise Terrorism Act. (November 27, 2006). Public Law 109-374. Available: https://www.congress.gov/109/plaws/publ374/PLAW-109publ374.pdf

Animal Liberation Front. (n.d.). Available: http://dictionnaire.sensagent.leparisien.fr/Фронт\%гоосвобождения\% 2оживотных/ru-ru/

Anti-Terrorism and Effective Death Penalty Act. (1996). Public Law 104-132. U.S. Government. Available: https://www.congress.gov/104/plaws/publ132/PLAW-104publi32.htm 
Berkowicz, S. M., Alpas, H., \& Ermakova, I. (2011). Eco-terrorism/Enviro-terrorism: background, prospects, countermeasures. In: H. Alpas, S. Berkowicz \& I. Ermakova (Eds.), Environmental security and ecoterrorism. NATO Science for Peace and Security Series C: Environmental Security (pp. 15-29). Dordrecht: Springer.

Blishchenko, V. (2013). Ponyatie "terrorizm" v zakonodatelstve SShA [The "terrorism" concept in the US legislation]. Counterting Terrorism. Problems of the XXI Century - Counter-Terrorism, 2, 15-24.

Committee of Secretaries of Security Councils CSTO. (2016, June 8). Perechen organizatsii, priznannykh terroristicheskimi i ekstremistskimi v gosudarstvakh - chlenakh ODKB [The list of organizations recognized as terrorist and extremist in states, CSTO members]. Available: https://antiterror.odkb-csto.org/terror_orgs/

Criminal Code of the Russian Federation No. 63-FZ. (June 13, 1996). Available: http://www.kremlin.ru/acts/bank/9555

Dubovik, O. L. (2018). Kriminologicheskie i ugolovno-pravovye predposylki borby s ekologicheskim terrorizmom i ekologicheskim ekstremizmom v Rossii [Criminological, criminal and legal perquisites of fighting against environmental terrorism, including in Russia]. Lex Russica, 9(142), 75-90.

Earth First! (n.d.). Kiev Ecological and Cultural Center. Available: http://ecoethics.ru/old/b36/o3.html

Efremov, A. E. (2017). Etapy razvitiya zakonodatelstva SShA po borbe s terrorizmom posle 11 sentyabrya 2001 goda [The stages of developing the U.S. legislation on the fight against terrorism after September 11, 20o1]. Zhurnal zarubezhnogo zakonodatelstva i sravnitelnogo pravovedeniya, 3, 89-94.

Ekologicheskii terrorizm [Ecoterrorism]. (n.d.). Available: https://dic.academic.ru/dic.nsf/ruwiki/1346976

Eko-terrorizm [Ecoterrorism]. (n.d.). Available: https://ru.qaz.wiki/wiki/Eco-terrorism

Ekstremizm. Made in USA. "Prestupleniya nenavisti" ugrozhayut amerikanskomu obshchestvu [Extremism. Made in USA. Hate crimes threatens the American society]. (n.d.). Available: http://hellishamerica.ru/terrorist yvusa.html

Executive Order of the Government of the Russian Federation No. 1225-r. (August 31, 2002). "On Environmental Doctrine of the Russian Federation"]. Available: http://www.consultant.ru/document/cons_doc_LAW_9209 7/ .

FBR: ekoterroristy - novaya ugroza Amerike [FBI: ecoterrorists as a new threat to the USA]. (n.d.). Available: https://www.newsru.com/world/2omay2005/fbiter.html

Federal Bureau of Investigation. (n.d.). Terrorism. Available: https://www.fbi.gov/investigate/terrorism

Federal Law No. 114-FZ. (July 25, 2002) "On Combating Extremist Activity". http://www.kremlin.ru/acts/bank/18939

Federal Law No. 35-FZ. (March 6, 2006). "On Countering Terrorism". Available: http://www.kremlin.ru/acts/bank/23522

Federal Law No. 492-FZ. (December 30, 2020). "On Biological Safety in the Russian Federation". Available: http://www.kremlin.ru/acts/bank/46353

Federal Security Service of the Russian Federation. (2021). Edinyi federalnyi spisok organizatsii, $v$ tom chisle inostrannykh i mezhdunarodnykh organizatsii, priznannykh v sootvetstvii s zakonodatelstvom Rossiiskoi Federatsii terroristicheskimi [The Unified Federal Register of Organizations, both foreign and international, recognized as terrorist under the Russian legislation]. Available: http://www.fsb.ru/fsb/npd/terror.htm

Fedorov, A. V. (Ed.). Superterrorizm: novyi vyzov novogo veka [Superterrorism: a new challenge of a new time]. Moscow: Prava cheloveka, 2002, 392 p.

Foreign terrorist organizations. (n.d.). Available: https://www.state.gov/foreign-terrorist-organizations/

Jarboe, J. F. (2002, February 12). The threat of eco-terrorism. Federal Bureau of Investigation. Available: https://web.archive.org/web/20080311231725/http://www.fbi.gov/congress/congresso2/jarboeo21202.htm

Kudryavtsev, A. V. (2000). "Vakhkhabizm": problemy religioznogo ekstremizma na Severnom Kavkaze ["Wahhabism": religious extremism on the Northern Caucasus]. Tsentralnaya Aziya i Kavkaz, 3(9), 115-122.

Law of Ukraine No. 638-IV. (March 20, 2003). "On the Fight against Terrorism". Verkhovna Rada of Ukraine. Available: https://zakon.rada.gov.ua/laws/show/638-15\#Text

Mikhel, D. V., \& Borovik, M. A. (2010). Dvizheniya po zashchite zhivotnykh: istoriya, politika, praktika [Animal protection movements: history, politics and practice]. Zhurnal issledovanii sotsialnoi politiki, 8(2), $227-252$.

Music on Saturdays. Shoko Asahara. Peremeny. (2007, March 24). Available: http://www.peremeny.ru/blog/523

Nakamura, Y. (1997). Zlo i grekh v yaponskoi kulture. Eshche raz ob "AUM Sinrike" [Evil and sin in the Japanese culture. One more time about "Aum Shinrikyo"]. Inostrannaya literatura, 8, 227-241.

Ovchinskii, V. S., \& Kochubei, M. A. (2009). Ekstremistskie organizatsii v SShA [Extremist organizations in the USA]. Zhurnal rossiiskogo prava, 26, 101-113.

Petchesky, R. P. (1981). Antiabortion, antifeminism, and the rise of the new right. Feminist Studies, 7(2), 206-246.

Rev. Donald Spitz. (n.d.). Pro-Life Virginia. Army of God. Available: http://www.armyofgod.com

Ryzhenkov, A. Ya. (2017). Ekologicheskii terrorizm kak globalnaya problema sovremennosti [Ecoterrorism as a global problem of modern times]. Legal Concept, 16(2), 27-35.

Sea Shepherd conservation group declared 'pirates' in US court ruling. (March 1, 2013). InterPravo. Available: https://pravo.ru/interpravo/news/view/83109/ 
Serebrennikova, A. V., \& Lebedev, M. V. (2019). Ugolovnaya otvetstvennost za terrorizm po ugolovnomu kodeksu respubliki Gruziya [Criminal liability for terrorism according to the Criminal Code of the Republic of Georgia]. Colloquium-journal, 15-10(39), 18-19.

Shofield, T. (1999). The environment as an ideological weapon: a proposal to criminalize environmental terrorism. Boston College Environmental Affairs Law Review, 26(3), 619-648.

Someone steals... (1995, November 25). Gazeta "Kommersant", No. 2019, p. 19. Available: https://www.kommersan t.ru/doc/122456

Supotnitskii, M. V. (2004, September 8) Chisto biologicheskoe ubiistvo [Purely biological murder]. NG. Available: https://www.ng.ru/style/2004-09-08/16_murder.html

Supotnitskii, M. V. (2013). Biologicheskaya voina [Biological war]. Monograph. Moscow: Russkaya panorama: Kafedra, 1136 p.

The Biological Weapons Anti-Terrorism Act of 1989 (BWATA). (May 22, 1990). Public Law 101-298. U.S. Government. Available: https://www.congress.gov/bill/1o1st-congress/senate-bill/993/text

The Covenant, Sword, Arm of The Lord - James Ellison - Kansas City 10oA-16708. (n.d.). Available: https://archive.org/details/CovenantSwordArmOfTheLordJamesEllisonKansasCity10oA16708

The Homeland Security Act (HSA). (November 25, 2002). Public Law 107-296-. U.S. Government. Available: https://www.dhs.gov/sites/default/files/publications/hr_5005_enr.pdf

The mystery of "Aum" in Russia. (2013, February 28). Available: http://iriney.ru/sektyi-i-kultyi/sektyiubijczyi/aum-sinrikyo/tajnaya-deyatelnost-\% $\mathrm{C}_{2} \% \mathrm{ABaum} \% \mathrm{C}_{2} \% \mathrm{BB}-\mathrm{v}$-rossii.html

The Penal Code of France. (2019, December 6). Available: https://constitutions.ru/?p=25017

The United States Code (U.S.C.). (n.d.). Available: https://www.law.cornell.edu/uscode/text

Tislenko, D. I. (2013). Ekologicheskii terrorizm [Environmental terrorism]: monograph. Moscow: Yurlitinform, 2013, $208 \mathrm{p}$.

USA Freedom Act. (June 6, 2015). Public Law 114-23. U.S. Government. Available: https://www.congress.gov/bill/ 114th-congress/house-bill/2048/text

USA Patriot Act. (October 26, 2001) Public Law 107-56. US Government Publishing Office. Available: https://www.congress.gov/107/plaws/publ56/PLAW-107publ56.pdf

Yamineva, Yu. B., \& Khvoshchev, V. E. (n.d.). Sovremennyi mir: vozrastanie ugroz ekologiche-skogo terrorizma [Modern world: growing threats of environmental terrorism]. Department of Political Science, South Ural State University, Chelyabinsk. Available: https://polit.susu.ru/articles/enviroterrorism.shtml

Zubarev, A. A. (2017). Protivodeistvie ekologicheskomu terrorizmu i ego pravovoe regulirovanie [The fight against ecoterrorism and its legal regulation]. Rostovskii nauchnyi zhurnal, 5, 36-43. 